Article

\title{
Chemical Composition and Determination of the Antibacterial Activity of Essential Oils in Liquid and Vapor Phases Extracted from Two Different Southeast Asian Herbs-Houttuynia cordata (Saururaceae) and Persicaria odorata (Polygonaceae)
}

\author{
Kristýna Řebíčková ${ }^{1}$, Tomáš Bajer ${ }^{1}$, David Šilha ${ }^{2}$, Markéta Houdková ${ }^{3}$, Karel Ventura $^{1}$ and \\ Petra Bajerová ${ }^{1, *(D)}$ \\ 1 Department of Analytical Chemistry, Faculty of Chemical Technology, University of Pardubice, \\ Studentská 573, 53210 Pardubice, Czech Republic; kristyna.rebickova@student.upce.cz (K.ॅ..); \\ tomas.bajer@upce.cz (T.B.); karel.ventura@upce.cz (K.V.) \\ 2 Department of Biological and Biochemical Sciences, Faculty of Chemical Technology, \\ University of Pardubice, Studentská 573, 53210 Pardubice, Czech Republic; david.silha@upce.cz \\ 3 Department of Crop Sciences and Agroforestry, Faculty of Tropical AgriSciences, Kamýcká 129, \\ Czech University of Life Sciences Prague, 16500 Prague, Czech Republic; houdkovam@ftz.czu.cz \\ * Correspondence: petra.bajerova@upce.cz; Tel.: +420-466-037-078
}

Academic Editor: Derek J. McPhee

Received: 30 April 2020; Accepted: 20 May 2020; Published: 22 May 2020

\begin{abstract}
Essential oils obtained via the hydrodistillation of two Asian herbs (Houttuynia cordata and Persicaria odorata) were analyzed by gas chromatography coupled to mass spectrometry (GC-MS) and gas chromatography with flame ionization detector (GC-FID). Additionally, both the liquid and vapor phase of essential oil were tested on antimicrobial activity using the broth microdilution volatilization method. Antimicrobial activity was tested on Gram-negative and Gram-positive bacteria-Escherichia coli, Staphylococcus aureus, Pseudomonas aeruginosa, Enterococcus faecalis, Streptococcus pyogenes, Klebsiella pneumoniae, Seratia marcescense and Bacillus subtilis. Hydrodistillation produced a yield of $0.34 \%$ (Houttuynia cordata) and $0.40 \%$ (Persicaria odorata). 41 compounds were identified in both essential oils. Essential oils contained monoterpenes and their oxidized forms, sesquiterpenes and their oxidized forms, oxidized diterpenes, derivates of phenylpropene and other groups, such as, for example, aldehydes, alcohols or fatty acids. Both essential oils were antimicrobial active in both vapor and liquid phases at least in case of one bacterium. They expressed various antimicrobial activity in the range of $128-1024 \mu \mathrm{g} \cdot \mathrm{mL}^{-1}, 512-1024 \mu \mathrm{g} \cdot \mathrm{mL}^{-1}$ in broth and $1024 \mu \mathrm{g} \cdot \mathrm{mL}^{-1}, 512-1024 \mu \mathrm{g} \cdot \mathrm{mL}^{-1}$ in agar, respectively. Research showed new interesting information about P. odorata and H. cordata essential oils and demonstrated that both essential oils could be possibly used in the field of natural medicine or natural food preservation.
\end{abstract}

Keywords: Houttuynia cordata; Persicaria odorata; essential oil; distillation; antimicrobial activity; vapor phase; volatile compounds; gas chromatography

\section{Introduction}

In recent years, many researchers have been focused on finding new antimicrobial agents that could be applied to multi-resistant microorganisms. Medicinal herbs and their products, such as essential oils (EOs), are the main source of natural remedies. They have been used since the time immemorial as the most affordable means of treating diseases. As it has been proven several times, EOs have 
diverse biological properties. They are bactericidal, viricidal, fungicidal, antiparasitic, antioxidant and insecticidal [1-3]. EOs and their components have activity against a variety of targets, particularly the membrane and cytoplasm, and, in some cases, they can completely change the morphology of the cells [4]. They contain a wide range of complex and structurally different compounds that are biologically, respectively, antimicrobially active. Antimicrobial activity is closely related to the chemical composition of EOs, functional groups and possible synergic interactions among constituents. In addition, due to the combination of these active compounds, bacteria are more difficult to develop a resistance to these compounds in comparison with commercial antimicrobials, which are usually based on one chemical substance [5]. In order to use EOs for treating various diseases caused by bacteria, it is important to understand to the relationship between their chemical composition and the potential antimicrobial activity.

EOs are volatile, and their vapors influence their antimicrobial properties. Therefore, it is necessary to sufficiently investigate the composition and properties of the vapors of essential oil. Currently, several researchers have investigated the vapor phase of the essential oil, but it deserves much wider research and consideration when examining the properties of essential oils [6-12]. It is assumed that active compounds in both phases are synergic and furthermore it has been shown that vapor phase is sometimes even more effective than liquid phase to some microorganisms. If biologically active molecules were present in the vapor phase, there would be, for example, the possibility of using EOs for the inhalation and treatment of respiratory diseases $[8,9]$. Furthermore, there would be the possibility of using these properties of EOs to produce various food packaging materials that protect food against the spread of microorganisms and extend their shelf life [13-15].

Traditionally, agar dilution, broth dilution or broth microdilution methods have been used to measure the minimal inhibitory concentrations of antimicrobial agents against microorganisms [16,17]. Unfortunately, these methods have been limited to measuring the minimal inhibitory concentrations (MICs) of antimicrobials only in the liquid phase. In the last few years, several methods and the modification-testing MICs of antimicrobials in the vapor phase were developed. Usually, the disc volatilization method with various modifications is used [10-12,17,18].

Two Southeast Asian herbs (Houttuynia cordata and Persicaria odorata), used mainly in the traditional Chinese medicine and as a spice in Asian cuisine, have been chosen for this study. These two herbs have been chosen for their known health benefits from Chinese medicine and for their geographical occurrence. Moreover, there is a lack of scientific literature about Houttuynia cordata [19-24] and Persicaria odorata [25,26] EOs. Therefore, they were examined in more detail. Houttuynia cordata, also known as a fish mint, belongs to a family Saururaceae. It is a flowering perennial herb native to Southeast Asia and it grows in moist shady places [27]. EOs from $H$. cordata have a fishy scent and show a variety of biological activities, such as antimicrobial, antiviral, anti-inflammatory, anticancer and insect repellent [28]. According to the previous reports, the liquid phase of EOs from $H$. cordata has inhibitory effects against Pseudomonas aeruginosa, Escherichia coli, Bacillus cereus, Bacillus subtilis, Vibrio cholerae and Staphylococcus aureus [21,29]. The dominant volatile compounds are houttuynin, myrcene, decanal, cis-ocimene and bornyl acetate $[27,28,30]$. Persicaria odorata, also known as a Vietnamese coriander, belongs to a family Polygonaceae. It is a tender perennial herb native to Southeast Asia and it grows in wet environments with a rich, moist soil shady places [25]. EOs isolated from P. odorata have a very strong coriander odor and show antimicrobial, anti-inflammatory, antitumor and antioxidant activity. According to the previous reports, the liquid phase of essential oil from P. odorata inhibits Salmonella choleraesuis [31], Enterococcus faecalis, Enterococcus faecium, Staphylococcus epidermidis and Staphylococcus aureus [32]. The most abundant volatile compounds are dodecanal, decanal, 3-hexanal, 2-hexanal, $\beta$-caryophyllene and $\alpha$-humulene [25,26,33,34].

Due to the growing demand for natural products and in light of the prevalence of pharmaceuticals, antioxidants or food additives in the food preservation process, it is necessary to find new sources for developing these products and to specify their properties. Plant-derived essential oils have received significant attention in this field. The aim of this study was to find herbs used both in the cuisine and 
natural medicine and determine their EOs composition and especially their antimicrobial efficiency in both vapor and liquid phase. In this study were two EOs obtained by hydrodistillation and thereafter analyzed by standard techniques GC-MS and GC-FID. Antimicrobial activity was determined by the modern, recently developed method of Houdkova et al. [35] called the broth microdilution volatilization method. It is a simple and rapid simultaneous determination of the antibacterial potential of plant volatile compounds in the liquid and the vapor phase at different concentrations [35].

\section{Results and Discussion}

\subsection{Extraction Yield and Chemical Composition}

Hydrodistillation in the Clevenger-type apparatus of Houttuynia cordata produced a pale-yellow liquid with a fishy scent. The essential oil content of distilled aerial parts of dried plant was $0.34 \%$. The extraction yield is higher in comparison with those previously published by R. S. Verma et al. [24] who only achieved a yield of $0.06-0.14 \%$. A total of 41 compounds were identified that made up $90.6 \%$ of the essential oil composition (Table 1). The essential oil contained a higher amount of terpenoid compounds (75.5\%), followed by non-terpenoid compounds $(15.1 \%)$, such as derivates of phenylpropene, aldehydes, ketones, esters and fatty acids. The major group of substances was monoterpenes with a content of $59.4 \%$, followed by the group of other compounds with a content of $14.8 \%$, oxidized monoterpenes with a content of $7.2 \%$ and sesquiterpenes with a content of $6.6 \%$. Other groups were oxidized sesquiterpenes and derivates of phenylpropene. Major compounds of the essential oil were myrcene (51.6\%), 2-undecanone $(6.7 \%)$, tridecan-2-one $(6.1 \%)$, cis- $\beta$-ocimene $(5.7 \%)$, geranyl acetate $(3.1 \%)$, bornyl acetate $(2.9 \%)$ and cis-caryophyllene $(2.6 \%)$. The other compounds were present at less than $2 \%$. These results are similar with the results of previous reports $[19,22,24]$. Only a few fluctuations from other reports were found and are probably attributed to the origin of the plant samples or different extraction method. For the characteristic fishy scent and flavoring of $H$. cordata essential oils is responsible compound houttuynin (decanoyl acetaldehyde). This compound was not identified in our essential oil due to its instability. It is usual that decanoyl acetaldehyde is during the process of distillation easily oxidized into 2-undecanone [24]. This compound had the second highest concentration in our essential oil. Therefore, the amount of 2-undecanone is the primary indicator for the quality of Houttuynia cordata essential oil [23,24].

Table 1. Chemical composition of essential oils from Houttuynia cordata and Persicaria odorata.

\begin{tabular}{|c|c|c|c|c|c|c|}
\hline \multirow[t]{2}{*}{ Compound } & \multirow[t]{2}{*}{ CAS Number } & \multirow[t]{2}{*}{ Identification $^{1}$} & \multicolumn{2}{|c|}{ Retention Index } & \multicolumn{2}{|c|}{ Peak Area [\%] } \\
\hline & & & Observed & Published $^{2}$ & H. cordata & P. odorato \\
\hline \multicolumn{7}{|l|}{ Monoterpenes } \\
\hline$\alpha$-pinene & $80-56-8$ & MS, RI & 930 & 933 & 0.53 & - \\
\hline camphene & $79-92-5$ & MS, RI & 946 & 953 & 0.36 & - \\
\hline$\beta$-pinene & $127-91-3$ & MS, RI & 974 & 978 & 0.45 & - \\
\hline myrcene & $123-35-3$ & MS, RI, Std & 993 & 991 & 51.64 & - \\
\hline limonene & $138-86-3$ & MS, RI, Std & 1027 & 1030 & 0.49 & - \\
\hline cis- $\beta$-ocimene & $3338-55-4$ & MS, RI & 1036 & 1040 & 5.72 & - \\
\hline trans- $\beta$-ocimene & $3779-61-1$ & MS, RI & 1046 & 1046 & 0.18 & - \\
\hline 7-epi-sesquithujene & $159407-35-9$ & MS, RI & 1387 & 1387 & - & 0.02 \\
\hline Sum $[\%]$ & & & & & 59.37 & 0.02 \\
\hline \multicolumn{7}{|c|}{ Oxidized monoterpenes } \\
\hline perillene & $539-52-6$ & MS, RI & 1097 & 1098 & 0.51 & - \\
\hline linalool & $78-70-6$ & MS, RI, Std & 1100 & 1101 & 0.28 & - \\
\hline myroxide & $33281-83-3$ & MS, RI & 1131 & 1129 & 0.01 & - \\
\hline isoborneol & $10385-78-1$ & MS, RI & 1169 & 1165 & 0.08 & - \\
\hline$\alpha$-terpineol & $98-55-5$ & MS, RI, Std & 1193 & 1195 & 0.06 & - \\
\hline$\beta$-cyclocitral & $432-25-7$ & MS, RI & 1218 & 1219 & - & 0.04 \\
\hline trans-geraniol & $102-24-1$ & MS, RI & 1251 & 1255 & 0.2 & - \\
\hline bornyl acetate & $92618-89-8$ & MS, RI & 1283 & 1285 & 2.85 & - \\
\hline neryl acetate & $141-12-8$ & MS, RI & 1358 & 1365 & 0.12 & - \\
\hline geranyl acetate & $105-87-3$ & MS, RI, Std & 1378 & 1383 & 3.11 & - \\
\hline Sum $[\%]$ & & & & & 7.22 & 0.04 \\
\hline
\end{tabular}


Table 1. Cont.

\begin{tabular}{|c|c|c|c|c|c|c|}
\hline \multirow[t]{2}{*}{ Compound } & \multirow[t]{2}{*}{ CAS Number } & \multirow[t]{2}{*}{ Identification $^{1}$} & \multicolumn{2}{|c|}{ Retention Index } & \multicolumn{2}{|c|}{ Peak Area [\%] } \\
\hline & & & Observed & Published $^{2}$ & H. cordata & P. odorata \\
\hline \multicolumn{7}{|l|}{ Sesquiterpenes } \\
\hline trans- $\alpha$-bergamotene & $13474-59-4$ & MS, RI & 1431 & 1432 & 0.1 & 0.25 \\
\hline isogermacrene D & $317819-80-0$ & MS, RI & 1441 & 1447 & - & 0.08 \\
\hline trans-caryophyllene & $87-44-5$ & MS, RI & 1452 & 1451 & 0.99 & - \\
\hline selina-4.11-diene & $17627-30-4$ & MS, RI & 1476 & 1482 & 1.13 & 0.23 \\
\hline$\alpha$-curcumene & $644-30-4$ & MS, RI & 1482 & 1480 & - & 0.23 \\
\hline$\beta$-selinene & $17066-67-0$ & MS, RI & 1487 & 1491 & - & 0.40 \\
\hline valencene & $4630-07-3$ & MS, RI & 1490 & 1492 & 0.67 & 0.04 \\
\hline$\beta$-bisabolene & $4891-79-6$ & MS, RI & 1508 & 1508 & - & 0.07 \\
\hline Sum $[\%]$ & & & & & 6.25 & 11.54 \\
\hline \multicolumn{7}{|l|}{ Oxidized sesquiterpenes } \\
\hline$\beta$-elemene & $33880-83-0$ & MS, RI & 1387 & 1390 & 0.13 & - \\
\hline ishwarane & $26620-70-2$ & MS, RI & 1465 & 1468 & 0.24 & - \\
\hline$\alpha$-farnesene & $502-61-4$ & MS, RI & 1503 & 1504 & 0.18 & - \\
\hline$\beta$-nerolidol & $40716-66-3$ & MS, RI & 1560 & 1561 & 0.76 & 0.53 \\
\hline spathulenol & $72203-24-8$ & MS, RI & 1575 & 1576 & 0.37 & - \\
\hline caryophyllene oxide & $1139-30-6$ & MS, RI & 1580 & 1587 & 0.99 & 1.42 \\
\hline humulene epoxide II & 19888-34-7 & MS, RI & 1608 & 1613 & - & 1.09 \\
\hline caryophylla-4(12).8(13)-dien-5-ol & $19431-80-2$ & MS, RI & 1632 & 1636 & - & 0.69 \\
\hline epi- $\beta$-bisabolol & $235421-59-7$ & MS, RI & 1669 & 1675 & - & 0.34 \\
\hline Sum $[\%]$ & & & & & 0 & 0.38 \\
\hline \multicolumn{7}{|l|}{ Derivates of phenylpropene } \\
\hline methyl eugenol & $93-15-2$ & MS, RI & 1401 & 1403 & 0.25 & - \\
\hline Sum $[\%]$ & & & & & 0.25 & 0 \\
\hline \multicolumn{7}{|l|}{ Others } \\
\hline 6-methyl-hept-5-en-2-one & $110-93-0$ & MS, RI & 985 & 986 & 0.05 & - \\
\hline 2-pentyl-furan & $3777-69-3$ & MS, RI & 993 & 991 & - & 0.06 \\
\hline 6-methyl-Hept-5-en-2-ol & $1569-60-4$ & MS, RI & 998 & 995 & - & 0.03 \\
\hline$n$-undecane & $1120-21-4$ & MS, RI & 1101 & 1100 & - & 2.52 \\
\hline n-nonanal & $124-19-6$ & MS, RI & 1104 & 1107 & 0.12 & 0.26 \\
\hline 1-nonanol & $143-08-8$ & MS, RI & 1172 & 1169 & 0.33 & 0.35 \\
\hline$n$-decanal & $112-31-2$ & MS, RI, Std & 1208 & 1208 & 0.15 & 18.4 \\
\hline 1-decanol & $112-30-1$ & MS, RI & 1276 & 1278 & - & 5.37 \\
\hline 2-undecanone & $112-12-9$ & MS, RI & 1293 & 1294 & 6.67 & - \\
\hline$n$-undecanal & $112-44-7$ & MS, RI & 1307 & 1309 & - & 1.37 \\
\hline 1-undecanol & $112-42-5$ & MS, RI & 1377 & 1379 & - & 1.16 \\
\hline 2-dodecanone & $6175-49-1$ & MS, RI & 1393 & 1393 & 0.07 & - \\
\hline n-dodecanal & $112-54-9$ & MS, RI, Std & 1411 & 1410 & 0.02 & 37.08 \\
\hline 1-dodecanol & $112-53-8$ & MS, RI, Std & 1477 & 1476 & - & 4.81 \\
\hline tridecan-2-one & $593-08-8$ & MS, RI & 1496 & 1495 & 6.06 & - \\
\hline$n$-dodecanoic acid & $143-07-7$ & MS, RI & 1569 & 1570 & 0.70 & - \\
\hline n-tetradecanal & $124-5-4$ & MS, RI & 1612 & 1614 & - & 0.26 \\
\hline
\end{tabular}

${ }^{1}$ MS - mass spectra, RI-retention index, Std-analytical standard; ${ }^{2}$ Data published in database ofNational Institute of Standards and Technology (NIST) [36] and Adams [37]. 
Hydrodistillation in Clevenger-type apparatus of Persicaria odorata produced a deep yellow liquid with a strong spicy coriander-like aroma. Due to its aroma, it is also called Vietnamese coriander [25]. The essential oil content of distilled aerial parts of dried plant was $0.41 \%$. The extraction yield is lower in comparison with those previously published by A. A. Almarie et al. [33] who achieved a yield of $0.64 \%$. A total of 41 compounds were identified that made up $90.4 \%$ of the essential oil composition. In comparison with other reports, we identified more compounds [38,39]. N. X. Dung et al. [38] used steam distillation for the isolation of essential oils and they identified 28 compounds and the most abundant were $\beta$-caryophyllene, dodecanal and caryophyllene oxide. M. V. Hunter et al. [39] only identified 17 compounds using steam distillation as an extraction technique for the isolation of essential oil from $P$. odorata, where the most abundant compounds were $\alpha$-humulene, decanal and dodecanal. Our essential oil contained a higher amount of non-terpenoid compounds (72.7\%) followed by terpenoid compounds (17.7\%). Carbonyls and alcohols, especially C10 and C12, made up $68.8 \%$ of essential oil composition, followed by the group of sesquiterpenes with a content of $11.5 \%$ and oxidized sesquiterpenes with a content of $5.7 \%$. Other groups (monoterpenes, oxidized monoterpenes and oxidized diterpenes) made up less than $1 \%$ of essential oil constitution. The major compounds of the essential oil were $n$-dodecanal (37.1\%), $n$-decanal (18.1\%), 1-decanol (5.4\%), 1-dodecanol $(4.8 \%)$, $\alpha$-humulene (4.5\%), cis-caryophyllene (3.9\%) and $n$-undecane $(2.5 \%)$. The other compounds were present at less than $2 \%$. These results in relative percent content are similar with the results of previous reports. It can clearly be seen that the essential oil from Persicaria odorata is rich in C10 and C12 carbonyls. Dodecanal and decanal are the main compounds of Persicaria odorata essential oil in all previous published reports and ours [25,33,38,39].

When comparing both EOs, it was found that they have only 12 common compounds out of 41 but they vary in the percent content. The essential oil from Hottuynia cordata contained much more monoterpenes and monoterpenoids, where the most abundant compound was myrcene (51\%) that was not found in the essential oil from the P. odorata. On the other hand, the essential oil from Persicaria odorata contained more sesquiterpenes, sesquipterpenoids and especially aldehydes, where $n$-dodecanal (37.1\%) was the dominant compound compared to H. cordata essential oil, where it was only $0.02 \%$. In general, the composition of both essential oils is different. The results are adequate because both herbs are neither from the same genus nor family, so their similarity in composition was not expected. They were selected for this study according to their similar use and same geographical occurrence.

\subsection{Antimicrobial Activity}

The antimicrobial activity of $H$. cordata and P. odorata essential oils is reported in Table 2. Both EOs showed antimicrobial efficiency but in different concentrations. H. cordata and P. odorata essential oil expressed various antimicrobial activity in the range of $128-1024 \mu \mathrm{g} \cdot \mathrm{mL}^{-1}, 512-1024 \mu \mathrm{g} \cdot \mathrm{mL}^{-1}$ in broth and $1024 \mu \mathrm{g} \cdot \mathrm{mL}^{-1}, 512-1024 \mu \mathrm{g} \cdot \mathrm{mL}^{-1}$ in agar, respectively. In the liquid phase, the lowest MIC was showed for H. cordata $\left(128 \mu \mathrm{g} \cdot \mathrm{mL}^{-1}\right)$ against E. faecalis and for P. odorata $\left(512 \mu \mathrm{g} \cdot \mathrm{mL}^{-1}\right)$ against S. pyogenes, E. faecalis and B. subtilis. In the vapor phase, the lowest MIC was observed for $H$. cordata $\left(1024 \mu \mathrm{g} \cdot \mathrm{mL}^{-1}\right)$ against E. faecalis and E. coli and for P. odorata $\left(512 \mu \mathrm{g} \cdot \mathrm{mL}^{-1}\right)$ against $E$. coli. There are observable differences between the efficiency of the vapor and liquid phases of observed essential oils (EOs). In most cases, the higher MIC reached the liquid phase, except in the case of EOs from P. odorata on E. coli, where the vapor phase was twice as effective as the liquid phase.

In general, Gram-negative bacteria are more resistant to EOs than Gram-positive bacteria [40]. This is supported by our results because, as it is shown in Table 2, Gram-positive bacteria were more sensitive to tested EOs in comparison with Gram-negative bacteria. It is possible that active compounds in EOs can more easily break important bonds (peptidoglycan) in the cell wall structure of Gram-positive bacteria. The structure of the Gram-positive bacteria cell wall allows hydrophobic molecules to easily penetrate the cells and act on both the cell wall and within the cytoplasm. After the cell wall is broken, the reactive constituents of the essential oil can penetrate the interior of the cell and further damage its DNA. The other fact is that phenolic compounds, which are also present in the EOs, 
generally show antimicrobial activity against Gram-positive bacteria. On the other hand, the cell wall of Gram-negative bacteria is far more complex, and it is, among other reasons, why they are more resistant to biologically active compounds (EOs) [4].

Table 2. Antimicrobial activity of tested essential oils and antibiotic ampicillin against Gram-negative and Gram-positive bacteria.

\begin{tabular}{|c|c|c|c|c|c|c|}
\hline \multirow{3}{*}{ Bacterium } & \multicolumn{6}{|c|}{ Sample/Growth/MIC $\left(\mu \mathrm{g} \cdot \mathrm{mL}^{-1}\right)$} \\
\hline & \multicolumn{2}{|c|}{ Houttuynia cordata } & \multicolumn{2}{|c|}{ Persicaria odorata } & \multicolumn{2}{|c|}{ Ampicillin } \\
\hline & Agar & Broth & Agar & Broth & Agar & Broth \\
\hline \multicolumn{7}{|l|}{ Gram negative } \\
\hline Escherichia coli & 1024 & 512 & 512 & 1024 & $>4$ & 0.50 \\
\hline Pseudomonas aeruginosa & $>1024$ & $>1024$ & $>1024$ & 1024 & $>4$ & 1.00 \\
\hline Klebsiella pneumoniae & $>1024$ & 1024 & $>1024$ & 1024 & $>4$ & $>4.00$ \\
\hline Serratia marcescens & $>1024$ & 1024 & $>1024$ & $>1024$ & $>4$ & 4.00 \\
\hline \multicolumn{7}{|l|}{ Gram positive } \\
\hline Staphylococcus aureus & $>1024$ & 1024 & $>1024$ & $>1024$ & $>4$ & 0.50 \\
\hline Enterococcus faecalis & 1024 & 128 & $>1024$ & 512 & $>4$ & 0.25 \\
\hline Streptococcus pyogenes & $>1024$ & 512 & 1024 & 512 & $>4$ & 1.00 \\
\hline Bacillus subtilis & $>1024$ & $>1024$ & $>1024$ & 512 & $>4$ & 2.00 \\
\hline
\end{tabular}

The most abundant compound in H. cordata essential oil is myrcene. Myrcene has an antimicrobial activity and moreover enhances the activity of antibiotics [41]. EOs with a high content of myrcene have a positive effect on urinary and genital infections [42,43]. These infections may be caused among others by E. coli and E. faecalis; therefore, we could assume that EOs from $H$. cordata will affect them, which has been confirmed in this study. The most abundant compound in P. odorata essential oil was $\alpha$-humulene, which is known for its anti-inflammatory effect. It is well known that EOs with $\alpha$-humulene are natural antimicrobial agents [44-46]. Pichette et al. [46] have tested the antimicrobial activity of $\alpha$-humulene against $E$. coli and $S$. aureus using the microdillution method. $\alpha$-humulene exhibited an MIC of $2.6 \mu \mathrm{g} \cdot \mathrm{mL}^{-1}$ against $S$. aureus and an MIC of more than $20 \mu \mathrm{g} \cdot \mathrm{mL}^{-1}$ against E. coli. Jang et al. [45] have tested the antimicrobial activity of $\alpha$-humulene against $B$. fragilis and obtained MIC of $0.5 \mu \mathrm{g} \cdot \mathrm{mL}^{-1}$. The high content of $\alpha$-humulene could be the reason why P. odorata EOs inhibited the growth of six from eight tested bacteria. On the other hand, there is one possible disadvantage when using these oils orally or internally, which is possible irritation or allergy caused by cis-caryophyllene, which both EOs contains [47]. It would be necessary to further examine the negative effect of each compound in the essential oil on the human body before using it for treating illness.

As far as authors know, there are no previous reports about Persicaria odorata and Houttuynia cordata essential oils and its antimicrobial activity in the vapor phase, so it is not possible to further compare those results with other publications. However, there are some reports about testing the liquid phase of EOs from Houttuynia cordata. Verma et al. [24] tested the antimicrobial activity of the essential oil from Houttuynia cordata against four bacteria (Staphylococcus aures, Streptococcus mutans, Mycobacterium smegmatis and Enteroccocus faecalis). Their essential oil exhibited MIC in the range of $0.52-1.04 \mu \mathrm{L} \cdot \mathrm{mL}^{-1}$. Ji et al. [20] performed a disc diffusion test to determine antimicrobial activity of $H$. cordata essential oil against Bacillus subtilis, Escherichia coli and Staphylococcus aureus; unfortunately, the disc diffusion test is only a screening method, which is not possible to compare with MIC. Lu et al. [22] tested the antimicrobial activity of $H$. cordata EOs against Staphylococcus aureus and Sarcina ureae using the broth and agar dilution method. Their reached minimal inhibitory concentration was in the range of $0.5-1.0 \mu \mathrm{L} \cdot \mathrm{mL}^{-1}$. 


\section{Materials and Methods}

\subsection{Plant Material}

Approximately $120 \mathrm{~g}$ of fresh Chinese herbs (H. cordata and P. odorata) was purchased in a local Vietnamese market (TTTM Sapa, Prague, Czech Republic). Each sample was air dried in a dark room at the laboratory's temperature. Prior to the distillation, both herbs, including leaves and stems, were crushed into smaller pieces.

\subsection{Essential Oil Isolation}

Essential oils were obtained by hydrodistillation using Clevenger-type apparatus. The EOs was prepared as follows: $26.7 \mathrm{~g}$ (H. cordata) or $18.4 \mathrm{~g}$ (P. odorata) of dried herb was weighted into a $2000 \mathrm{~mL}$ distillation flask, $1000 \mathrm{~mL}$ of water was added and the EOs was distilled for $4 \mathrm{~h}$. The essential oil was then separated from hydrosol and stored in sealed dark-glass vials at $4{ }^{\circ} \mathrm{C}$ until the analysis.

\subsection{Bacterial Strains and Culture Media}

Four Gram-negative and four Gram-positive bacteria that caused respiratory infections, including upper and lower airway diseases, were chosen. Standard strains were used for the experiment: Escherichia coli CCM 3954, Pseudomonas aeruginosa CCM 3955, Klebsiella pneumoniae NPK12, Serratia marcescens CCM 303, Staphylococcus aureus CCM 4223, Enterococcus faecalis CCM 4224, Streptococcus pyogenes NPK01 and Bacillus subtilis CCM 2215. All standard strains were purchased from Czech Collection of Microorganisms (CCM), Brno, Czech Republic. Bacteria were incubated at $37^{\circ} \mathrm{C}$ for $24 \mathrm{~h}$. Prior to the experiment, bacterial suspensions with turbidity according to the McFarland scale were prepared corresponding to the grade $0.5\left(\sim 1.5 \times 10^{8} \mathrm{CFU} \cdot \mathrm{mL}^{-1}\right)$. The cultivation and assay media were Mueller-Hinton (agar and broth; Himedia, India). The $\mathrm{pH}$ of the broth was adjusted to a final value of 7.6 using Trizma base and hydrochloric acid (both Himedia, India). Ampicilin (St. Louis, MO, USA) was used as a positive antibiotic control.

\subsection{Antimicrobial Activity Assay}

The antimicrobial activity of the liquid and vapor phase of Eos was determined by the broth microdilution volatilization method [35]. The experiments were carried out in 96-well microtiter plates with one well volume of $400 \mu \mathrm{L}$. The test is designed for the testing of 6 essential oils in total. For this study, we tested only 2 essential oils, and different samples were in other wells. The plates were covered with wooden plates and clamped to prevent vapor phase leakage. The edge wells were left blank to avoid the edge effect. First, essential oil samples were prepared as follows: approximately $2 \mu \mathrm{L}$ of EOs was added to corresponding amount of dimethyl sulfoxide (DMSO) at a concentration of $1 \%$, then further diluted in the corresponding broth to initial concentration. Then, the antibiotic was prepared at an initial concentration of $4 \mu \mathrm{g} \cdot \mathrm{mL}^{-1}$. In the first part of the experiment, $30 \mu \mathrm{L}$ of agar was pipetted onto the plate lid and inoculated with $5 \mu \mathrm{L}$ of bacterial suspension for vapor phase testing. In the second part (liquid phase assay), $100 \mu \mathrm{L}$ of buffered Mueller-Hinton broth was pipetted into the wells. Each well had a final volume of $100 \mu \mathrm{L}$. Seven two-fold diluted concentrations of samples starting at a concentration of $1024 \mu \mathrm{g} \cdot \mathrm{mL}^{-1}$ were prepared for each essential oil in one row. A positive and negative control of bacterial growth was prepared in the first two columns. In the last column, 6 two-fold diluted concentrations of antibiotic starting at $4 \mu \mathrm{g} \cdot \mathrm{mL}^{-1}$ were prepared. Finally, all wells except the negative control were inoculated with $5 \mu \mathrm{L}$ of bacterial suspension. Plates were closed, fixed and incubated at $37^{\circ} \mathrm{C}$ for $24 \mathrm{~h}$. After incubation, minimal inhibitory concentrations of EOs were evaluated by the visual assessment of bacterial growth after the coloring of a metabolically active bacterial colony with thiazolyl blue tetrazolium bromide dye (MTT; Sigma Aldrich, Prague, Czech Republic). A total of $25 \mu \mathrm{L}$ of $600 \mu \mathrm{g} \cdot \mathrm{mL}^{-1}$ dye was applied to the lid and each well of the plate and equilibrated for $10 \mathrm{~min}$. The color changed from yellow (dead cells) to purple (live cells). Thereafter, the MICs were recorded. All experiments were performed in triplicate in three independent 
experiments. The results were expressed as the median of minimal inhibition concentration of the antimicrobial agent values.

\subsection{GC-MS Analysis}

The GC-MS analysis of samples was carried out by using a Gas Chromatograph GC 2010 coupled to a Mass Selective Detector GCMS-QP2010 Plus (both Shimadzu, Kyoto, Japan) and Combi Pal Autosampler (CTC Analytics, AG, Zwingen, Swizerland) on a capillary column SLB-5ms Supelco (30 m $\times 0.25 \mathrm{~mm}, 2.5 \mu \mathrm{m}$ film thickness; Bellefonte, PA, USA). The carrier gas was Helium 5.0 (Linde, Prague, Czech Republic) with a constant flow of $30 \mathrm{~cm} \cdot \mathrm{s}^{-1}$. The oven temperature program was set at an initial temperature of $40{ }^{\circ} \mathrm{C}$ for $3 \mathrm{~min}$, then heated up to $250{ }^{\circ} \mathrm{C}$ at $2{ }^{\circ} \mathrm{C} \cdot \mathrm{min}^{-1}$ and held at $250{ }^{\circ} \mathrm{C}$ for $10 \mathrm{~min}$. The injector and detector temperatures were set at $200^{\circ} \mathrm{C}$. The mass spectrometry detector was operated under electron ionization mode at ionization energy of $70 \mathrm{eV}$ when ions with $m / z$ 33-500 were scanned. A total of $1 \mu \mathrm{L}$ of diluted essential oil (200 times, $n$-hexane) was injected with a split ratio 1:50. The experimental results of retention indices were calculated relative to C8-C33 $n$-alkanes in concentrations of 100-200 $\mu \mathrm{g} \cdot \mathrm{mL}^{-1}$, dissolved in $n$-hexane (Restek, Bellefonte, PA, USA). The calculation was performed according to the van den Dool and Kratz method, and the results were further compared to published data [36,37]. Compounds were identified by comparing their mass spectra with mass spectra of several standards (Table 1) and commercial mass spectral databases NIST'14 Mass Spectral Library and FFNSC 2 GC/MS Library Release 2.0 (Flavor and Fragrance Natural and Synthetic Compounds Library) and further checked out by manual mass spectra evaluation.

\subsection{GC-FID Analysis}

The GC-FID analysis of samples was carried out by using a Gas Chromatograph GC 2010 with a flame ionization detector (Shimadzu, Kyoto, Japan) and Autosampler Combi Pal (CTC Analytics, AG, Zwingen, Swizerland) on a capillary column SLB-5ms Supelco (30 m $\times 0.25 \mathrm{~mm}, 2.5 \mu \mathrm{m}$ film thickness; Bellefonte, PA, USA). The GC-FID conditions were the same as in case of GC-MS analysis. The injector temperature was set at $200{ }^{\circ} \mathrm{C}$ and the detector temperature was set at $260{ }^{\circ} \mathrm{C}$. A total of $1 \mu \mathrm{L}$ of diluted essential oil (200 times, $n$-hexane) was injected with a split ratio 1:50. As in the case of GC-MS, experimental retention indices were calculated and compared to published data.

\section{Conclusions}

This study shows new interesting knowledge about EOs distilled from two Asian herbs—Persicaria odorata and Houttuynia cordata. The chemical composition of EOs corresponds to previous studies with a minor deviation that may be caused by agronomic factors, sample storage or sample preparation and other factors. Both EOs showed antimicrobial activity in different concentrations to different bacteria. Due to great antibacterial activity, along with the composition of Eos, we see a great potential for future usages of these oils, such as natural antimicrobials or food preservatives. As far as we know, we were the first to describe the antimicrobial properties of those EOs in both vapor and liquid phases on eight selected bacteria. Furthermore, it is necessary to study the possible cytotoxicity of these oils. The disadvantage is that both oils contain cis-caryophyllene that causes allergic reactions and skin irritation. It would be necessary to find the balance in concentrations of beneficial antimicrobial active compounds and potentially toxic compounds.

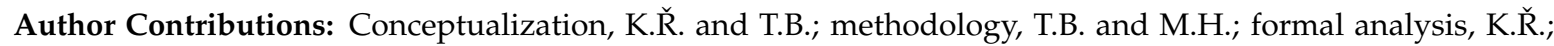

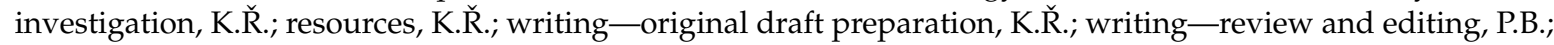
T.B. and D.Š.; supervision, K.V.; project administration, P.B. All authors have read and agreed to the published version of the manuscript.

Funding: This research received no external funding.

Conflicts of Interest: The authors declare no conflict of interest. 


\section{References}

1. Caputo, L.; Nazzaro, F.; Souza, L.F.; Aliberti, L.; De Martino, L.; Fratianni, F.; Coppola, R.; De Feo, V. Laurus nobilis: Composition of Essential Oil and Its Biological Activities. Molecules 2017, 22, 930. [CrossRef] [PubMed]

2. Merghni, A.; Marzouki, H.; Hentati, H.; Aouni, M.; Mastouri, M. Antibacterial and antibiofilm activities of Laurus nobilis L. essential oil against Staphylococcus aureus strains associated with oral infections. Curr. Res. Transl. Med. 2016, 64, 29-34. [CrossRef] [PubMed]

3. Rafiq, R.; Hayek, S.A.; Anyanwu, U.; Hardy, B.I.; Giddings, V.L.; Ibrahim, S.A.; Tahergorabi, R.; Kang, H.W. Antibacterial and Antioxidant Activities of Essential Oils from Artemisia herba-alba Asso., Pelargonium capitatum $x$ radens and Laurus nobilis L. Foods 2016, 5, 28. [CrossRef] [PubMed]

4. Nazzaro, F.; Fratianni, F.; De Martino, L.; Coppola, R.; De Feo, V. Effect of essential oils on pathogenic bacteria. Pharmaceuticals 2013, 6, 1451-1474. [CrossRef]

5. Kon, K.V.; Rai, M.K. Plant essential oils and their constituents in coping with multidrug-resistant bacteria. Expert Rev. Anti-Infect. Ther. 2012, 10, 775-790. [CrossRef]

6. Feyaerts, A.F.; Mathe, L.; Luyten, W.; Tournu, H.; Van Dyck, K.; Broekx, L.; Van Dijck, P. Assay and recommendations for the detection of vapour-phase-mediated antimicrobial activities. Flavour Frag. J. 2017, 32, 347-353. [CrossRef]

7. Houdkova, M.; Doskocil, I.; Urbanova, K.; Tulin, E.; Rondevaldova, J.; Tulin, A.B.; Kudera, T.; Tulin, E.E.; Zeleny, V.; Kokoska, L. Evaluation of antipneumonic effect of Philippine essential oils using broth microdilution volatilization method and their lung fibroblasts toxicity. Nat. Prod. Commun. 2018, 13, 1059-1066. [CrossRef]

8. Acs, K.; Bencsik, T.; Boszormenyi, A.; Kocsis, B.; Horvath, G. Essential oils and their vapors as potential antibacterial agents against respiratory tract pathogens. Nat. Prod. Commun. 2016, 11, 1709-1712.

9. Amat, S.; Baines, D.; Alexander, T.W. A vapour phase assay for evaluating the antimicrobial activities of essential oils against bovine respiratory bacterial pathogens. Lett. Appl. Microbiol. 2017, 65, 489-495. [CrossRef]

10. Reyes-Jurado, F.; Cervantes-Rincon, T.; Bach, H.; Lopez-Malo, A.; Palou, E. Antimicrobial activity of Mexican oregano (Lippia berlandieri), thyme (Thymus vulgaris), and mustard (Brassica nigra) essential oils in gaseous phase. Ind. Crops Prod. 2019, 131, 90-95. [CrossRef]

11. Santomauro, F.; Donato, R.; Pini, G.; Sacco, C.; Ascrizzi, R.; Bilia, A.R. Liquid and vapor-phase activity of Artemisia annua essential oil against pathogenic Malassezia spp. Planta Med. 2018, 84, 160-167. [CrossRef] [PubMed]

12. Torpol, K.; Wiriyacharee, P.; Sriwattana, S.; Sangsuwan, J.; Prinyawiwatkul, W. Antimicrobia activity of garlic (Allium sativum L.) and holy basil (Ocimum sanctum L.) essential oils applied by liquid vs. vapour phases. Int. J. Food Sci. Technol. 2018, 53, 2119-2128. [CrossRef]

13. Azadbakht, E.; Maghsoudlou, Y.; Khomiri, M.; Kashiri, M. Development and structural characterization of chitosan films containing Eucalyptus globulus essential oil: Potential as an antimicrobial carrier for packaging of sliced sausage. Food Packag. Shelf Life 2018, 17, 65-72. [CrossRef]

14. Chen, C.W.; Xu, Z.W.; Ma, Y.R.; Liu, J.L.; Zhang, Q.J.; Tang, Z.P.; Fu, K.J.; Yang, F.X.; Xie, J. Properties, vapour-phase antimicrobial and antioxidant activities of active poly(vinyl alcohol) packaging films incorporated with clove oil. Food Control 2018, 88, 105-112. [CrossRef]

15. Silva, F; Domingues, F.C. Antimicrobial activity of coriander oil and its effectiveness as food preservative. Crit. Rev. Food Sci. Nutr. 2017, 57, 35-47. [CrossRef]

16. Laird, K.; Phillips, C. Vapour phase: A potential future use for essential oils as antimicrobials? Lett. Appl. Microbiol. 2012, 54, 169-174. [CrossRef]

17. Ji, H.; Kim, H.; Beuchat, L.R.; Ryu, J.H. Synergistic antimicrobial activities of essential oil vapours against Penicillium corylophilum on a laboratory medium and beef jerky. Int. J. Food Microbiol. 2019, 291, 104-110. [CrossRef]

18. Doran, A.L.; Morden, W.E.; Dunn, K.; Edwards-Jones, V. Vapour-phase activities of essential oils against antibiotic sensitive and resistant bacteria including MRSA. Lett. Appl. Microbiol. 2009, 48, 387-392. [CrossRef]

19. Asakawa, Y.; Tomiyama, K.; Sakurai, K.; Kawakami, Y.; Yaguchi, Y. Volatile compounds from the different organs of Houttuynia cordata and Litsea cubeba (L. citriodora). J. Oleo Sci. 2017, 66, 889-895. [CrossRef] 
20. Ji, Y.B.; Yang, J.J.; Yu, M.; Cao, Y.; Guo, S.Z.; Qiao, A.N. Study on medicinal plant active substances extraction and antibacterial activity of Houttuynia cordata. In Proceedings of the 1st International Global on Renewable Energy and Development, Singapore, 22-25 December 2017; IOP Publishing Ltd: Bristol, UK, 2017; Volume 100.

21. Kwon, H.-D.; Cha, I.-H.; Lee, W.-K.; Song, J.-H.; Park, I.-H. Antibacterial activity of volatile flavor components from Houttuynia cordata Thunb. Prev. Nutr. Food Sci. 1996, 1, 208-213.

22. Lu, H.; Wu, X.; Liang, Y.; Zhang, J. Variation in chemical composition and antibacterial activities of essential oils from two species of Houttuynia THUNB. Chem. Pharm. Bull. 2006, 54, 936-940. [CrossRef] [PubMed]

23. Pang, J.; Dong, W.; Li, Y.; Xia, X.; Liu, Z.; Hao, H.; Jiang, L.; Liu, Y. Purification of Houttuynia cordata Thunb. essential oil using macroporous resin followed by microemulsion encapsulation to improve its safety and antiviral activity. Molecules 2017, 22, 293. [CrossRef] [PubMed]

24. Verma, R.S.; Joshi, N.; Padalia, R.C.; Singh, V.R.; Goswami, P.; Kumar, A.; Iqbal, H.; Verma, R.K.; Chanda, D.; Chauhan, A. Chemical composition and allelopathic, antibacterial, antifungal, and antiacetylcholinesterase activity of fish-mint (Houttuynia cordataThunb.) from India. Chem. Biodivers. 2017, 14, e1700189. [CrossRef] [PubMed]

25. Shavandi, M.A.; Haddadian, Z.; Ismail, M.H.S. Eryngium foetidum L. Coriandrum sativum and Persicaria odorata L.: A review. J. Asian Sci. Res. 2012, 2, 410.

26. Starkenmann, C.; Luca, L.; Niclass, Y.; Praz, E.; Roguet, D. Comparison of volatile constituents of Persicaria odorata (Lour.) Sojak (Polygonum odoratum Lour.) and Persicaria hydropiper L. Spach (Polygonum hydropiper L.). J. Agric. Food Chem. 2006, 54, 3067-3071. [CrossRef]

27. Dai, D.N.; Thang, T.D.; Ogunmoye, A.; Eresanya, O.I.; Ogunwande, I.A. Chemical constituents of essential oils from the leaves of Tithonia diversifolia, Houttuynia cordata and Asarum glabrum grown in Vietnam. Am. J. Essent. Oil. 2015, 2, 17-21.

28. Oh, S. An effective quality control of pharmacologically active volatiles of Houttuynia cordata Thunb by fast gas chromatography-surface acoustic wave sensor. Molecules 2015, 20, 10298-10312. [CrossRef]

29. Zhang, W.; Lu, F.; Pan, S.; Li, S. Extraction of volatile oil from Houttuynia cordata and its anti-biotic and anti-virus activities. Pract. Prev. Med. 2008, 15, 312-316.

30. Jiangang, F.; Ling, D.; Zhang, L.; Hongmei, L. Houttuynia cordata Thunb: A review of phytochemistry and pharmacology and quality control. Chin. Med. 2013, 4, 101-123.

31. Fujita, K.; Chavasiri, W.; Kubo, I. Anti-salmonella activity of volatile compounds of Vietnam coriander. Phytother. Res. 2015, 29, 1081-1087. [CrossRef]

32. Chansiw, N.; Paradee, N.; Chotinantakul, K.; Srichairattanakool, S. Anti-hemolytic, antibacterial and anti-cancer activities of methanolic extracts from leaves and stems of Polyg. odoratum. Asian Pac. J. Trop. Biomed. 2018, 8, 580-585. [CrossRef]

33. Almarie, A.; Mamat, A.; Wahab, Z.; Rukunudin, I. Chemical composition and phytotoxicity of essential oils isolated from Malaysian plants. Allelopath. J. 2016, 37, 55-69.

34. Murray, A.F.; Satooka, H.; Shimizu, K.; Chavasiri, W.; Kubo, I. Polygonum odoratum essential oil inhibits the activity of mushroom derived tyrosinase. Heliyon 2019, 5, e02817. [CrossRef] [PubMed]

35. Houdkova, M.; Rondevaldova, J.; Doskocil, I.; Kokoska, L. Evaluation of antibacterial potential and toxicity of plant volatile compounds using new broth microdilution volatilization method and modified MTT assay. Fitoterapia 2017, 118, 56-62. [CrossRef]

36. Linstrom, P.J.; Mallard, W. NIST Chemistry WebBook, NIST Standard Reference Database Number 69. Available online: https://webbook.nist.gov/chemistry/ (accessed on 30 April 2020).

37. Adams, R.P. Identification of Essential Oil Components by Gas Chromatography/Mass Spectrometry, 4th ed.; Allured Publishing Corporation: Carol Stream, IL, USA, 2007.

38. Dũng, N.X.; Van Hac, L.; Leclercq, P.A. Volatile constituents of the aerial parts of Vietnamese Polygonum odoratum L. J. Essent. Oil Res. 1995, 7, 339-340. [CrossRef]

39. Hunter, M.V.; Brophy, J.J.; Ralph, B.J.; Bienvenu, F.E. Composition of Polygonum odoratum Lour. from Southern Australia. J. Essent. Oil Res. 1997, 9, 603-604. [CrossRef]

40. Trombetta, D.; Castelli, F.; Sarpietro, M.G.; Venuti, V.; Cristani, M.; Daniele, C.; Saija, A.; Mazzanti, G.; Bisignano, G. Mechanisms of antibacterial action of three monoterpenes. Antimicrob. Agents Chemother. 2005, 49, 2474-2478. [CrossRef] 
41. Sieniawska, E.; Swatko-Ossor, M.; Sawicki, R.; Skalicka-Woźniak, K.; Ginalska, G. Natural terpenes influence the activity of antibiotics against isolated Mycobacterium tuberculosis. Med. Princ. Pract. 2017, 26, 108-112. [CrossRef]

42. Lis, A.; Banaszczak, P. Chemical composition of the essential oils from flowers and leaves of Phellodendron chinense CK Schneid. J. Essent. Oil-Bear. Plants 2010, 13, 52-58. [CrossRef]

43. Arnal-Schnebelen, B.; Hadji-Minaglou, F.; Peroteau, J.; Ribeyre, F.; De Billerbeck, V. Essential oils in infectious gynaecological disease: A statistical study of 658 cases. Int. J. Aromather. 2004, 14, 192-197. [CrossRef]

44. Fernandes, E.S.; Passos, G.F.; Medeiros, R.; da Cunha, F.M.; Ferreira, J.; Campos, M.M.; Pianowski, L.F.; Calixto, J.B. Anti-inflammatory effects of compounds alpha-humulene and (-)-trans-caryophyllene isolated from the essential oil of Cordia verbenacea. Eur. J. Pharmacol. 2007, 569, 228-236. [CrossRef] [PubMed]

45. Jang, H.-I.; Rhee, K.-J.; Eom, Y.-B. Antibacterial and antibiofilm effects of $\alpha$-humulene against Bacteroides fragilis. Can. J. Microbiol. 2020, 66, 1-11. [CrossRef] [PubMed]

46. Pichette, A.; Larouche, P.L.; Lebrun, M.; Legault, J. Composition and antibacterial activity of Abies balsamea essential oil. Phytother. Res. 2006, 20, 371-373. [CrossRef] [PubMed]

47. National Center for Biotechnology Information. PubChem Database. Available online: https://pubchem.ncbi. nlm.nih.gov/compound/Caryophyllene (accessed on 28 April 2020).

Sample Availability: Samples of the compounds are not available from the authors.

(C) 2020 by the authors. Licensee MDPI, Basel, Switzerland. This article is an open access article distributed under the terms and conditions of the Creative Commons Attribution (CC BY) license (http://creativecommons.org/licenses/by/4.0/). 